\title{
Wear properties of copper and copper composites powders consolidated by high-pressure torsion
}

\author{
Mohamed Ibrahim Abd El AAL ${ }^{1,2, *}$ \\ ${ }^{1}$ Mechanical Engineering Department, College of Engineering, Prince Sattam Bin Abdulaziz University, Wadi Addawaser 11991, Saudi Arabia \\ ${ }^{2}$ Mechanical Design \& Production Department, Faculty of Engineering, Zagazig University, Zagazig 44519, Egypt \\ Received: 24 July 2018 / Revised: 10 December 2018 / Accepted: 28 February 2019 \\ (C) The author(s) 2019.
}

\begin{abstract}
The wear characteristics of $\mathrm{Cu}$ and $\mathrm{Cu}-\mathrm{SiC}$ composite microsize powders consolidated by cold compaction combined with sintering or high-pressure torsion (HPT) were investigated. The HPT processed (HPTed) samples with bimodal and trimodal microstructures and fine $\mathrm{Cu}$ grains and $\mathrm{SiC}$ particle sizes have superior hardness, reasonable ductility level, and high wear resistance. The wear mass loss and coefficient of friction of HPTed samples were remarkably lower than that of cold-compacted and sintered samples as well as that of micro and nano $\mathrm{Cu}$ and $\mathrm{Cu}-\mathrm{SiC}$ composites from previous studies. The sample fabrication method has an apparent influence on the wear mechanism. The wear mechanism was converted from adhesive, delamination, three-body mechanism, grooves (take off the $\mathrm{SiC}$ particles), and cracks into abrasive wear after HPT. Oxidization can be considered a dominant wear mechanism in all cases. The worn surface morphology and analysis support the relationship between wear mechanism and characteristics.
\end{abstract}

Keywords: $\mathrm{Cu}-\mathrm{SiC}$ composite powders; high-pressure torsion (HPT); fine and coarse grains; wear characteristics; worn surface morphology

\section{Introduction}

The low wear resistance of pure $\mathrm{Cu}$ limits its usage in different industrial applications. The improvement of pure $\mathrm{Cu}$ hardness and wear characteristics can be performed by different methods including the fabrication of $\mathrm{Cu}$ composites [1,2]. Formation of $\mathrm{Cu}$ metal matrix composites (MMCs) improves the mechanical properties of $\mathrm{Cu}$ at low and high temperatures [2]. The advantages of particulate MMCs [3] have motivated different studies to improve the mechanical properties of pure $\mathrm{Cu}$ reinforced with ceramic particles [4-9]. Although powder metallurgy has many advantages [10], it suffers from various problems $[4,5]$, which have led to the search for new manufacturing methods for $\mathrm{Cu}$ MMCs.

The influence of grain and particle sizes of metals and MMCs on their wear properties is an important research topic. Understanding the effects of decreasing grain and particle sizes on the wear properties of metals and MMCs manufactured by different methods (e.g., high-pressure torsion (HPT)) was the motivation behind previous works [11-22]. However, contradictory results between the improvement [15-19, 20, 22] and deterioration [21] of wear characteristics of HPT processed (HPTed) materials were obtained.

No previous investigation has focused on the influence of HPT on the wear features of microsize MMC powders. Therefore, a new study on the effect of HPT of $\mathrm{Cu}$ and $\mathrm{Cu}$ composites on their wear characteristics is required. Present work aims to first, explore the influence of producing $\mathrm{Cu}$ and $\mathrm{Cu}$ MMCs with a microstructure that gathers between fine and coarse grain and particle sizes on their wear and

* Corresponding author: Mohamed Ibrahim Abd El AAL, E-mail: eng_mohabdelall@yahoo.com, miabdelaal@zu.edu.eg, mi.abdelaal@ psau.edu.safax 
frictional properties. Second, it explores the influence of the sample manufacturing process on morphologies and analyses of worn $\mathrm{Cu}, \mathrm{Cu} \mathrm{MMC}$, and Tungsten carbide (WC) ball surfaces. Finally, the present results are compared with the wear characteristics of as-cast $\mathrm{Cu}$ and previous works of micro, ultrafine grain (UFG), and nanometer microstructures $\mathrm{Cu}$ and $\mathrm{Cu}$ MMCs.

\section{Experimental work}

$\mathrm{Cu}$ and $\mathrm{Cu}-\mathrm{SiC}$ MMCs were fabricated by cold compaction combined with sintering or HPT of $\mathrm{Cu}$ and $\mathrm{SiC}$ powders, as shown in Fig. 1(a) and previously discussed in Ref. [23]. Solid as-cast pure Cu samples were machined and used for further comparison in the present study. Observations of the microstructure and characteristics of different samples were presented in previous work [23]. Microstructure characteristics (grain and particle sizes), and physical and mechanical properties of the cases are listed in Table 1 [23].

Dry sliding ball-on-flat reciprocating wear testsat sliding distances of 500-2500 $\mathrm{m}$ and applied loads of 5-30 N were conducted for all conditions, as shown in Fig. 1(b). The wear test conditions, parameters, and determination of the wear mass loss have been discussed previously [20]. The wear test was repeated five times for each condition and the average wear mass loss value was used. The influence of $\mathrm{SiC} \%$ and the applied load under different sliding distance on wear mass loss was plotted in the form of the grid pattern using OriginPro8 and a so-called wear map. The wear mass loss values in the wear map were recorded by following a regular grid pattern with placement/plotting of the $\mathrm{SiC} \%$ and applied load values along $\mathrm{X}$ - and $\mathrm{Y}$-axis, respectively. Worn surface morphologies and analysis were conducted by scanning electron microscope (SEM).

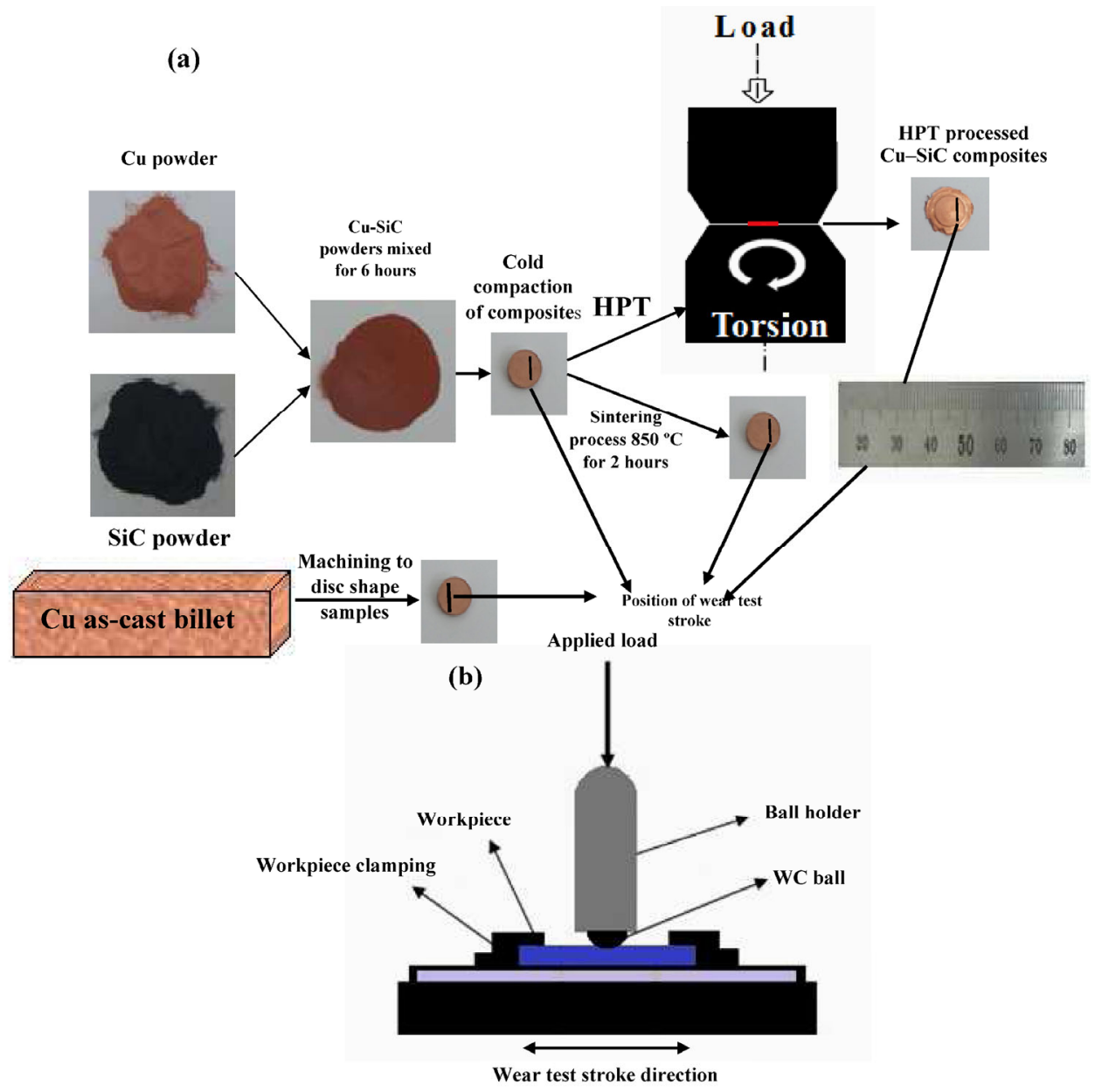

Fig. 1 Macrographs of (a) $\mathrm{Cu}$ and $\mathrm{Cu}-\mathrm{SiC}$ composites preparation flow chart and as-cast $\mathrm{Cu}$ sample with the position of the wear test, and (b) the ball-on-flat surface reciprocating sliding wear test. 
Table 1 Summary of microstructure, relative density, and mechanical properties parameters of the different samples [23].

\begin{tabular}{|c|c|c|c|c|c|c|c|c|c|c|}
\hline \multirow[b]{2}{*}{ Parameter } & \multicolumn{10}{|c|}{ Sample } \\
\hline & $\begin{array}{c}\text { Cu as- } \\
\text { cast }\end{array}$ & $\begin{array}{c}\text { Cu cold } \\
\text { compacted }\end{array}$ & $\begin{array}{c}\mathrm{Cu}- \\
10 \% \mathrm{SiC} \text { cold } \\
\text { compacted }\end{array}$ & $\begin{array}{c}\mathrm{Cu}- \\
20 \% \mathrm{SiC} \text { cold } \\
\text { compacted }\end{array}$ & $\begin{array}{c}\mathrm{Cu} \\
\text { sintered }\end{array}$ & $\begin{array}{c}\mathrm{Cu}- \\
10 \% \mathrm{SiC} \\
\text { sintered }\end{array}$ & $\begin{array}{c}\mathrm{Cu}- \\
20 \% \mathrm{SiC} \\
\text { sintered }\end{array}$ & $\begin{array}{c}\mathrm{Cu} \\
\mathrm{HPT}\end{array}$ & $\begin{array}{c}\mathrm{Cu}- \\
10 \% \mathrm{SiC} \\
\mathrm{HPT}\end{array}$ & $\begin{array}{c}\mathrm{Cu}- \\
20 \% \mathrm{SiC} \\
\mathrm{HPT}\end{array}$ \\
\hline $\begin{array}{l}\text { SiC particle size } \\
\operatorname{rang}(\mu \mathrm{m})\end{array}$ & - & - & $56-12.6$ & $56-12.6$ & - & $56-12.6$ & $56-12.6$ & - & $0.128-0.248$ & $0.071-0.104$ \\
\hline $\begin{array}{c}\text { SiC average } \\
\text { particle size }(\mu \mathrm{m})\end{array}$ & - & - & 25.5 & 25.5 & - & 25.5 & 25.5 & - & 0.137 & 0.078 \\
\hline $\begin{array}{l}\mathrm{Cu} \text { grain size } \\
\text { rang }(\mu \mathrm{m})\end{array}$ & $30.21-12.34$ & $67.94-15.02$ & $49.99-12.34$ & $46.04-11.42$ & $59.29-7.98$ & $44.96-4.43$ & $44.68-3.61$ & $2.25-0.05$ & $2.12-0.04$ & $0.76-0.03$ \\
\hline $\begin{array}{l}\mathrm{Cu} \text { average grain } \\
\text { size }(\mu \mathrm{m})\end{array}$ & 27.61 & 29.5 & 25.9 & 24.2 & 26.1 & 22.5 & 21 & 0.95 & 0.9 & 0.3 \\
\hline $\begin{array}{c}\text { Percent of UFG } \\
\text { and nano } \mathrm{Cu} \text { grain } \\
\text { sizes }(\%)\end{array}$ & - & - & - & - & - & - & - & 54 & 62 & 100 \\
\hline $\begin{array}{l}\text { Relative density } \\
\qquad(\rho)(\%)\end{array}$ & 100 & 97.8 & 96.4 & 94.6 & 98.9 & 98.4 & 95.5 & 99.7 & 99.6 & 99.4 \\
\hline Microhardness, Hv & 68 & 63 & 106 & 119 & 84.5 & 122.3 & 138.6 & 190.9 & 276.1 & 328.5 \\
\hline Elongation (\%) & - & - & - & - & 16.9 & 9.1 & 7.9 & 12.9 & 7.8 & 7 \\
\hline
\end{tabular}

\section{Results and discussion}

\subsection{Wear properties}

\subsubsection{Wear mass loss}

The wear mass loss curves shown in Fig. 2 indicate
$50 \%-775 \%$ and $100 \%-900 \%$ increase in wear mass loss with increasing of load and distance, respectively. On another hand, the increase in $\mathrm{SiC} \%$ decreased the mass loss owing to the increase in hardness [4-6, $9,13,14,23]$. The wear mass loss of different samples decreased by $27 \%-85 \%$ after the sintering process under
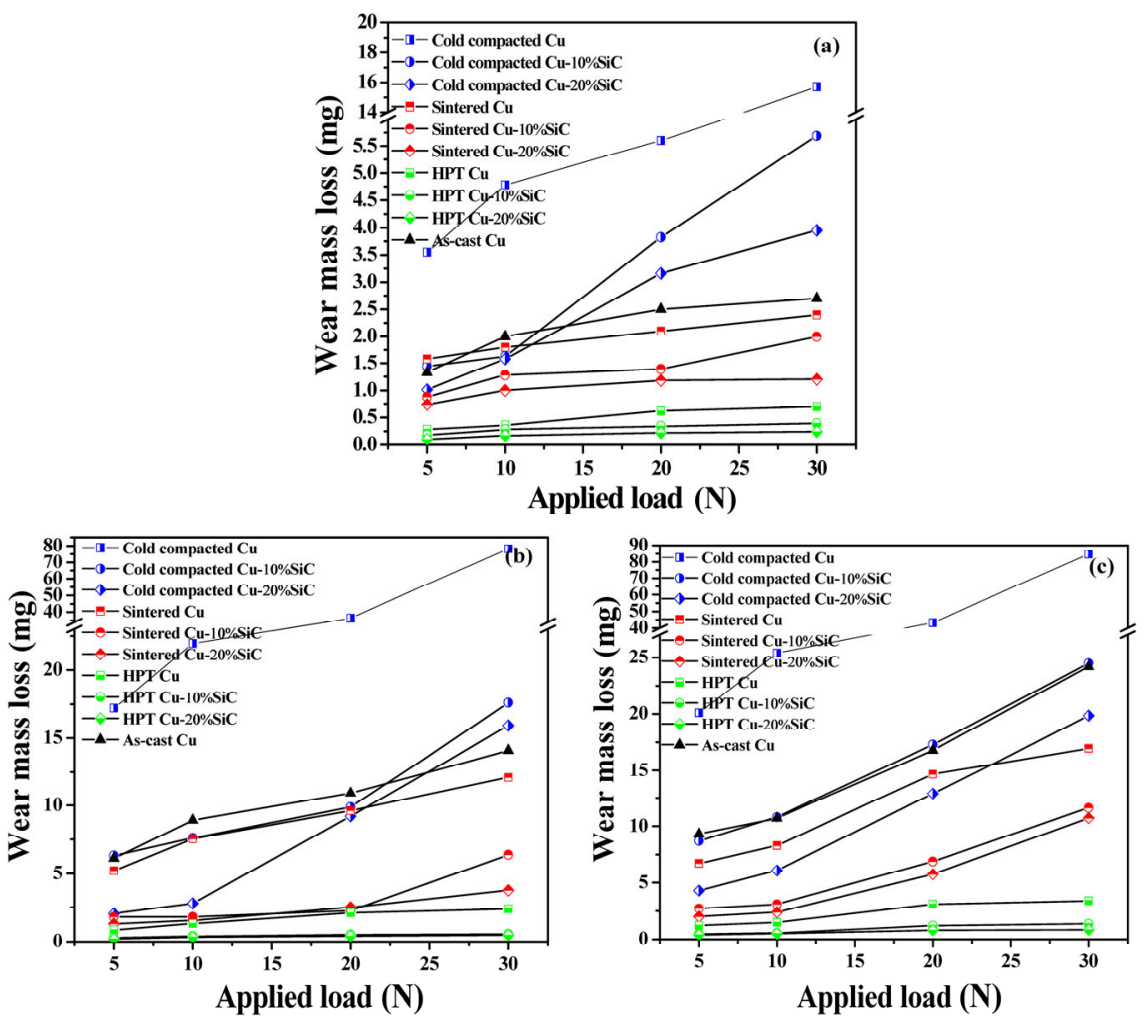

Fig. 2 The effect of the applied load on the wear mass loss of the as-cast $\mathrm{Cu}$, cold compacted, sintered, and $\mathrm{HPTed} \mathrm{Cu}$ and $\mathrm{Cu}-\mathrm{SiC}$ samples under different sliding distances (a) 500, (b) 1,500, and (c) 2,500 m. 
different conditions owing to the $34 \%-17 \%$ increase in microhardness, as shown in Table 1. This increase in microhardness after sintering is attributed to the decrease in void content; hence, bonding improved because of $\mathrm{Cu}$ diffusion [23]. Interestingly, the wear mass loss increased with the increase in the load at different sliding distances. However, the percentage increase in mass loss (in the form of the slope of wear mass loss curves) becomes clearer under applied loads from 20 to $30 \mathrm{~N}$ and increasing distance. The increase in sliding distance with higher applied load contributes to severe wear, which is more obvious in cold-compacted and sintered samples with lower hardness than in HTPed samples. The wear mass loss decreased at a higher rate after HPT than after the sintering process. The higher wear resistance obtained after HPT processing compared with cold compaction and sintering is attributed to the increase in hardness [24] achieved through the formationof a fully-dense microstructure with fine $\mathrm{Cu}$ grains and $\mathrm{SiC}$ particles, as shown in Table 1.
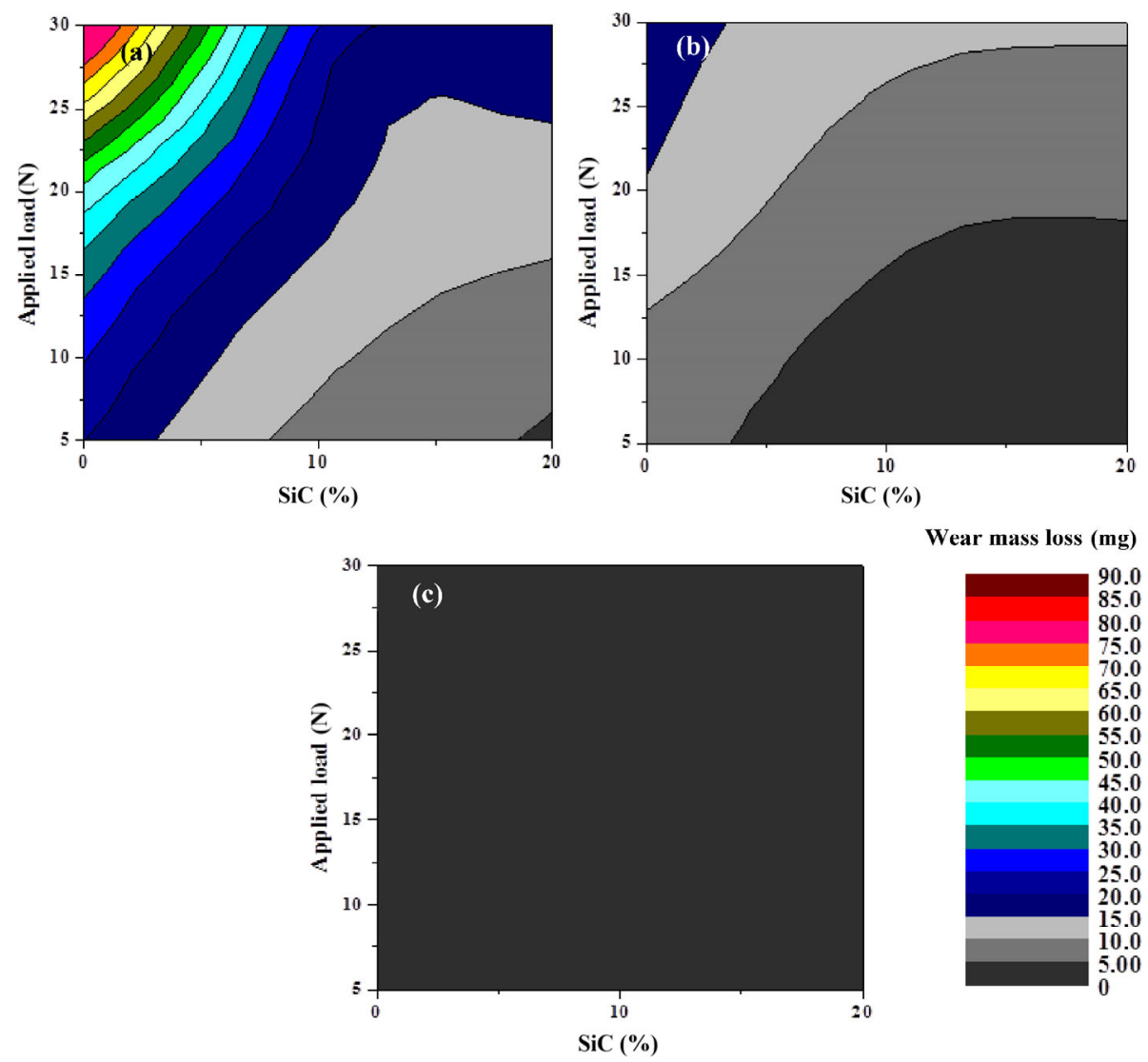

Wear mass loss (mg)

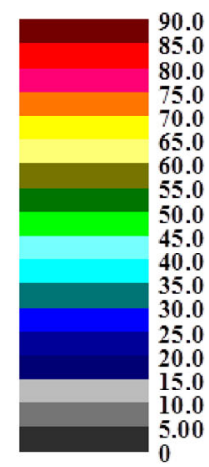

$\mathrm{SiC}(\%)$

Fig. 3 Wear mass loss map of (a) cold compacted, (b) sintered, and (c) HPTed $\mathrm{Cu}$ and $\mathrm{Cu}$-SiC composites samples under different applied load and sliding distances of $2,500 \mathrm{~m}$. 

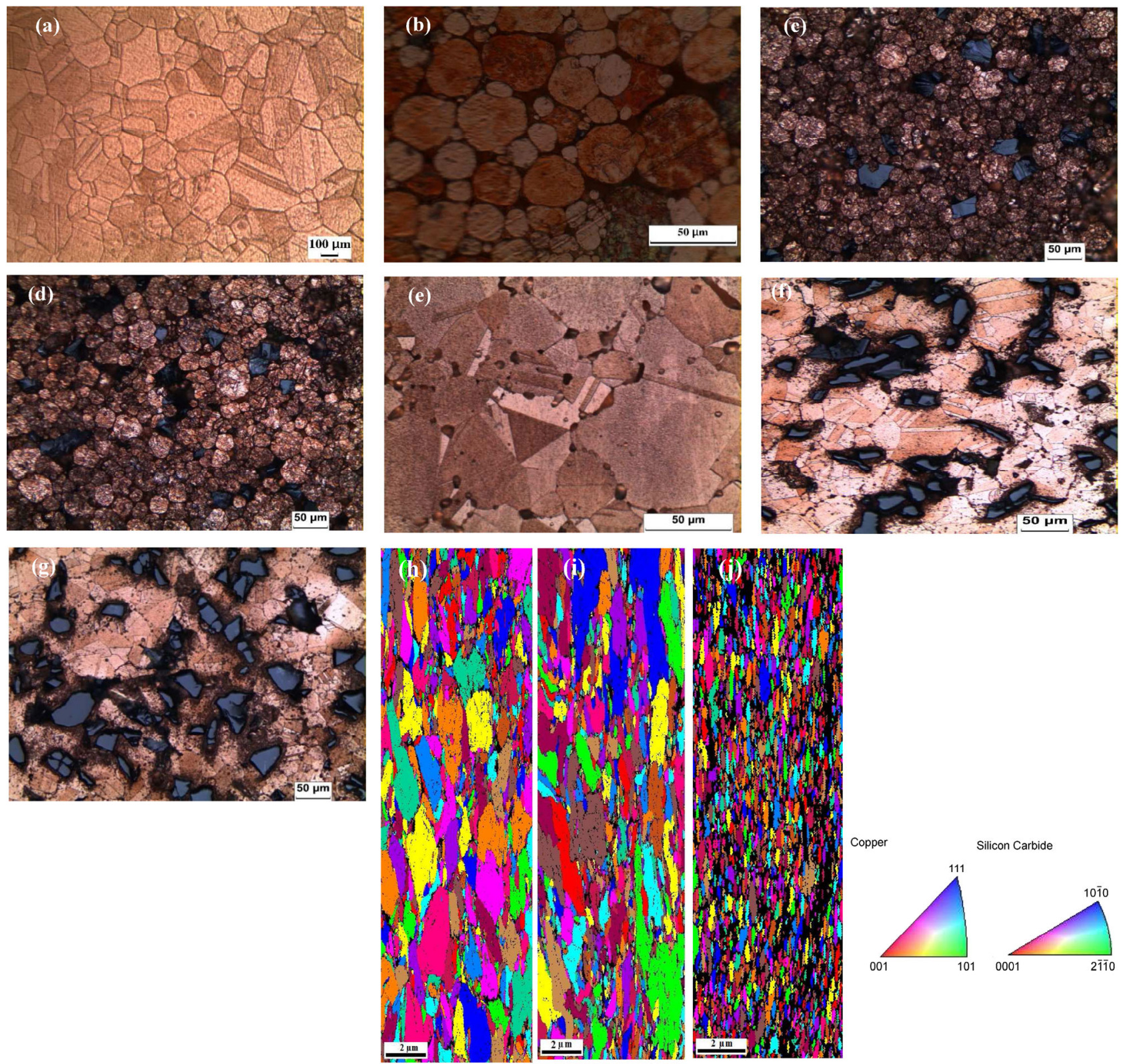

Fig. $4 \mathrm{OM}$ photomicrographs of the microstructure of (a) $\mathrm{Cu}$ as-cast, (b) $\mathrm{Cu}$, (c) $\mathrm{Cu}-10$, and (d) $20 \% \mathrm{SiC}$ cold compacted samples, (e) $\mathrm{Cu}$, (f) $\mathrm{Cu}-10$, and (g) $20 \% \mathrm{SiC}$ sintered samples, and EBSD color-coded orientation map images of (h) $\mathrm{Cu}$, (i) $\mathrm{Cu}-10$, and (j) $20 \% \mathrm{SiC} \mathrm{HPTed}$ samples.

These types of microstructures (bimodal or trimodal) improve the wear resistance of $\mathrm{Cu}$ MMCs compared with those with only micro- or nanomatrix grains and reinforcement particle sizes $[6,9,21]$. The high wear properties of the HPTed samples are also proved by comparing them with previous works $[4,6,7,9,11-14$, 17, 19, 25-27] as follows.

Figure 5 shows the comparison between the hardness and wear mass loss of $\mathrm{Cu}$ and $\mathrm{Cu}$ MMCs in the present work and $\mathrm{Cu}$ and $\mathrm{Cu}$ MMCs samples with microsize microstructure. It noted that the hardness and wear resistance of HPTed $\mathrm{Cu}$ and $\mathrm{Cu}$ MMCs were higher than those with matrix and reinforcement with sizes in the range 10-75 $\mu \mathrm{m}$ and hardness values in range $80-140 \mathrm{Hv}[4,6,7,9,13,14,25]$. This observation can be explained by the effects of the grain and particle refinement, which contribute to improving hardness, and hence reduced wear mass loss. 

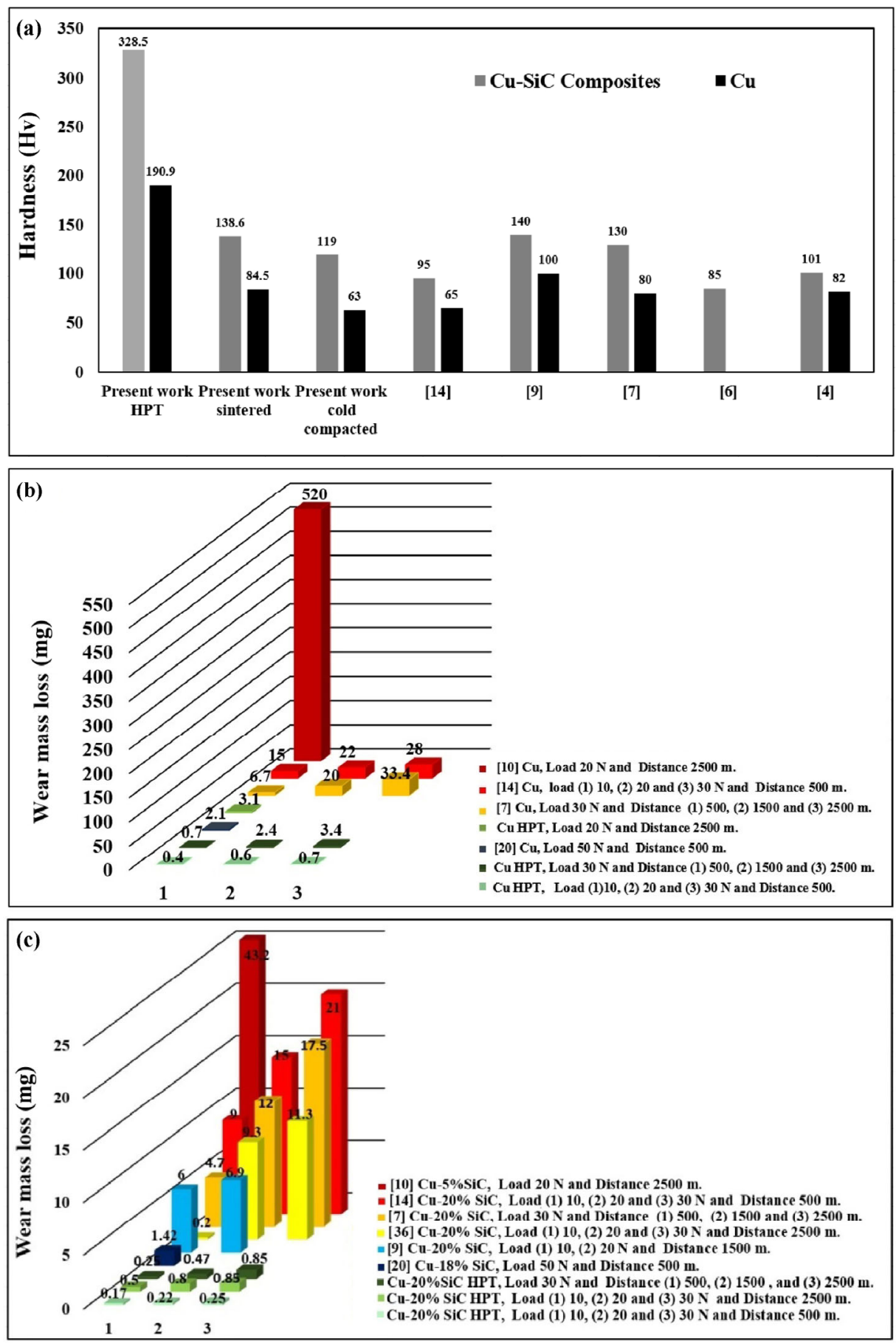

Fig. 5 Comparison between (a) hardness and wear mass loss of HPTed (b) $\mathrm{Cu}$ and (c) $\mathrm{Cu}$-SiC samples with previous works concerned with fabrication of micro size $\mathrm{Cu}$ and $\mathrm{Cu}$ composites samples.

The other part of the comparison is concerned with the comparison between the results of the present work and the $\mathrm{Cu}$ and $\mathrm{Cu}$ MMCs with UFG and nanosize microstructure [11, 12, 14, 17, 19, 26-29], as shown in Fig. 6. It noted that HPT processing reduces the wear mass loss of $\mathrm{Cu}$ by $55 \%-100 \%$ compared with that of $\mathrm{Cu}$ and $\mathrm{Cu}$ alloy with $50-800 \mathrm{~nm}$ grain sizes $[11,12,14,17,19]$. Thus, the $\mathrm{Cu}$ produced with a mixed microstructure of large and fine grain sizes (bimodal microstructure) is effective in improving wear resistance. Grain refinement contributes to the improvement of hardness, as shown in Figs. 5(a) 
and 6(a) and Table 1.

Although grain refinement increases the hardness and wear properties, it simultaneously decreases the ductility of samples [11, 12, 14, 17, 26-29]. The ductility decrease can be attributed to the increase in the grain boundary area [23]. The grain boundary area increase hinders dislocation movements which could accumulate within the grains that contribute to the enhancement of strength (hardness). Similar observations of the ductility decrease combined with grain refinement down to UFG or nanograin sizes owing to the effect of the increase in grain boundary area were previously noted in Refs. [30, 31]. Moreover, sliding during the wear test increased the strain hardening of the worn surface, increasing the possibility of crack formation and damage. Thus, the combination of hardness and
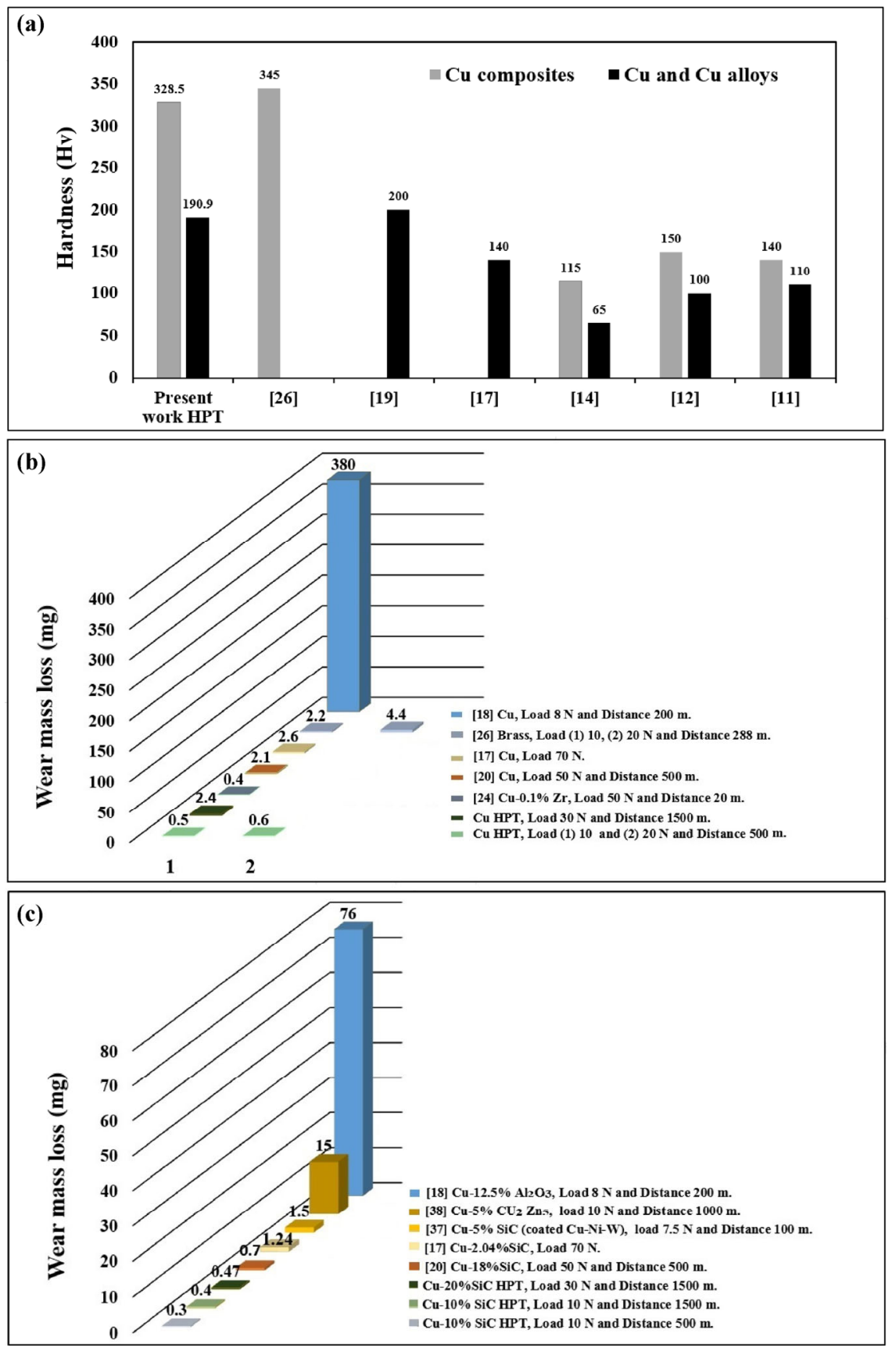

Fig. 6 Comparison between (a) hardness and wear mass loss of HPTed (b) $\mathrm{Cu}$ and (c) Cu-SiC samples with previous works concerned with fabrication of UFG and nanosize $\mathrm{Cu}$ and $\mathrm{Cu}$ composites samples. 
ductility through the formation of a bimodal microstructure is needed to improve wear resistance, i.e., a bimodal microstructure with a mixture of fine grains (that increase the hardness) and large grains (that improve ductility). Interestingly, the formation of such a microstructure conserves $80 \%$ of HPTed sample ductility, as indicated in Table 1, which reduces the degree of delamination and crack formation, resulting in reduced wear mass loss similar to that noted previously in Res. [29, 32].

The HPTed Cu MMCs have 25\%-100\% higher wear resistance than that of the MMC with ultrafine and nanomatrix grains and reinforcement sizes [11, 12, 14, 26-28], as summarized in Fig. 6(c). The high wear properties of HPTed $\mathrm{Cu}$ MMCs compared with MMCs with nanomatrix grains and reinforcement sizes [11, $12,14,26-28$ ] are because of the following reasons. The HPTed $\mathrm{Cu}$ composites were fabricated using microsizeSiC particles that enable the HPTed $\mathrm{Cu}$ MMC samples to acquire $\mathrm{SiC} \%$ (reaching 20\%) higher than $2.04 \%-18 \%$ achieved previously in Refs. [11, 12, 14, 26-28]. Furthermore, the degree of agglomeration decreased with a noticeable homogenized distribution of reinforcement, starting with microsize SiC particles compared with that noted in the case of MMCs fabricated using UF and nanosize materials [22, 23]. Finally, similar to the $\mathrm{Cu}$ samples, the formation of trimodal microstructure enhanced hardness by $300 \%$ and retained approximately $85 \%$ of the ductility of $\mathrm{Cu}$ MMC samples after HPT processing for improved wear resistance. The effects of combining high hardness with acceptable ductility level, which improve the mechanical and wear properties of the material, have been noted in previous works [29, 32-34].

The cold compaction of pure $\mathrm{Cu}$ powder was not effective in enhancing the wear resistance of pure $\mathrm{Cu}$ compared with as-cast $\mathrm{Cu}$. The wear resistance of as-cast $\mathrm{Cu}$ was $54 \%-82 \%$ higher than that of coldcompacted $\mathrm{Cu}$ under different conditions owing to the low microhardness of cold-compacted samples. The hardness and wear resistance of cold-compacted $\mathrm{Cu}$ samples increased after sintering and HPT processing, with reduced wear mass loss of $10 \%-30 \%$ and $87 \%-$ $74 \%$, respectively, compared with as-cast $\mathrm{Cu}$ samples. Therefore, sintering and HPTed processing of $\mathrm{Cu}$ powder can produce $\mathrm{Cu}$ samples with superior wear properties than that of solid $\mathrm{Cu}$ samples.

\subsubsection{Friction properties}

Figures 7(a)-7(d) show the curves of the coefficient of friction (COF) ofCu samples. The COF of the as-cast $\mathrm{Cu}$ sample increased to its maximum value at $200 \mathrm{~m}$,
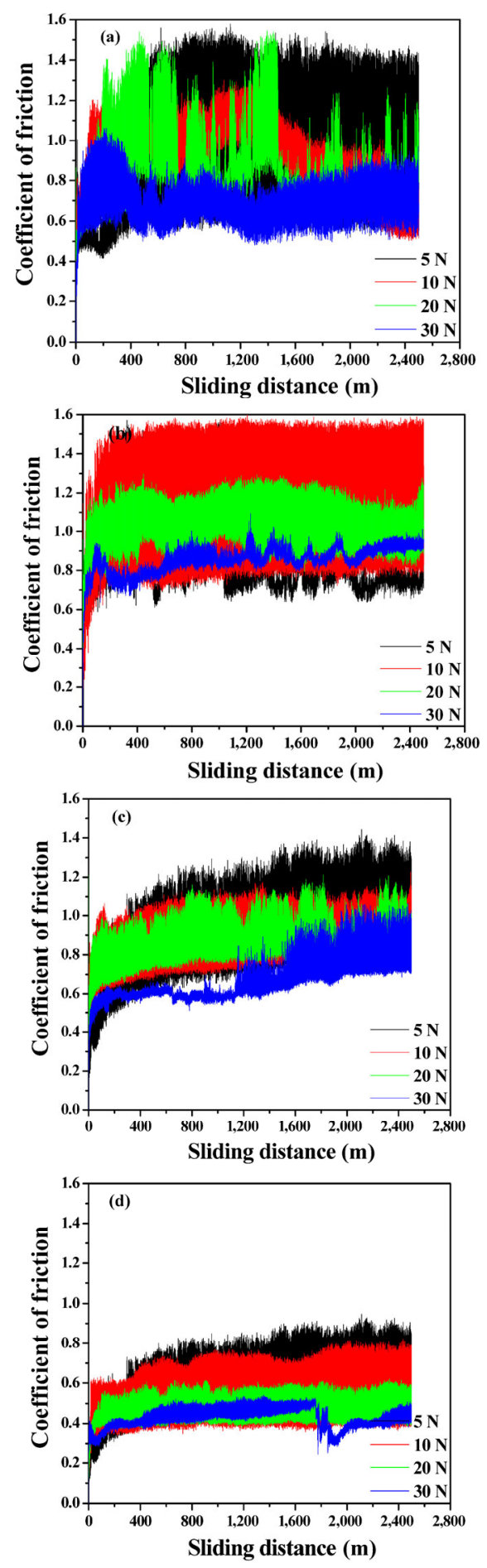

Fig. 7 Variation of COF under different applied loads and sliding distances of 2,500 of (a) as-cast, (b) cold compacted, (c) sintered, and (d) HPTed $\mathrm{Cu}$ samples. 
then oscillated around the maximum value as shown in Fig. 7(a). COF values of different $\mathrm{Cu}$ samples exhibit the same behavior, as shown in Fig. 7. Interestingly, the variation range of COF values of HPTed Cu samples decreased because of the increased hardness due to grain refinement $[13,17,18,20,29]$. The behavior of COF of $\mathrm{Cu}$ MMCs processed by different methods was similar to that noted in the case of $\mathrm{Cu}$ samples, but with smaller variation range owing to the higher hardness of $\mathrm{Cu}$ MMCs, as shown in Fig. 8 and previously noted in Refs. [8, 13, 14, 27, 28, 35].
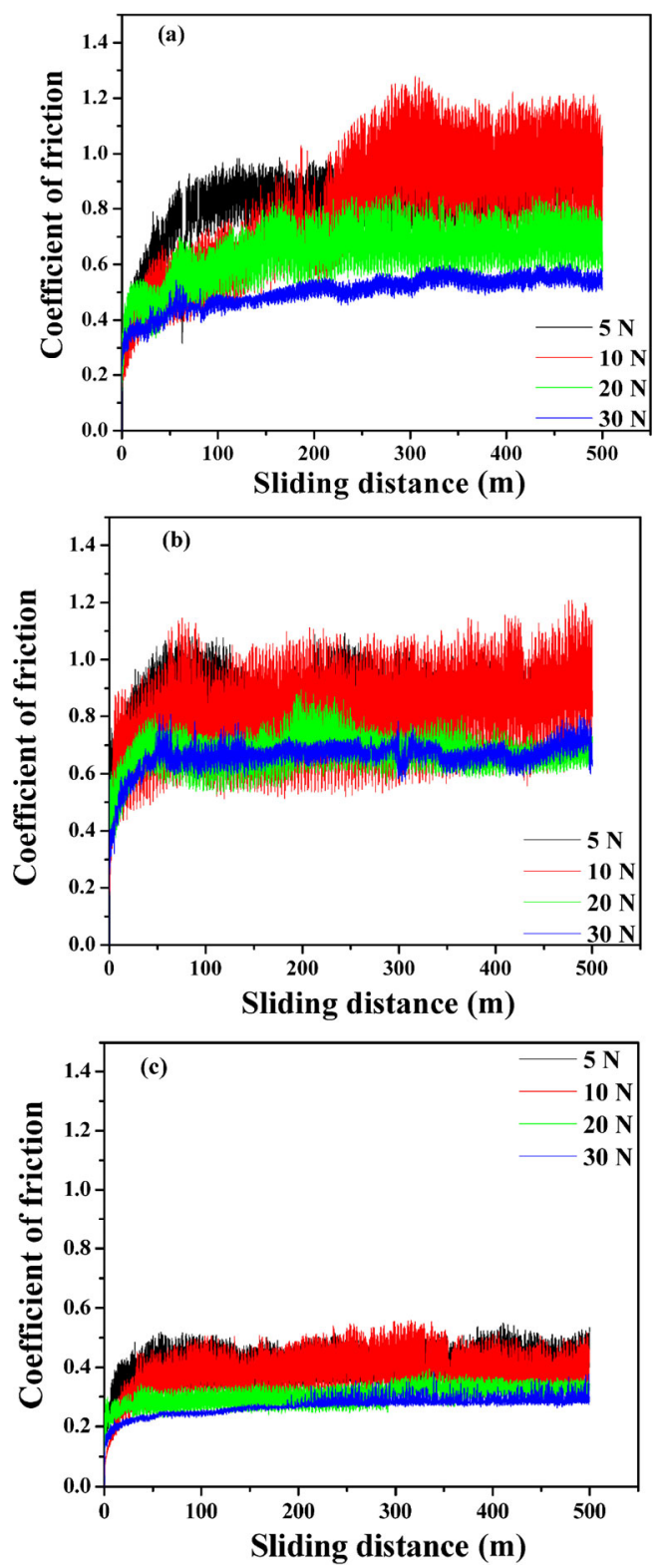

The average COF decreased by $5 \%-40 \%$ for all cases with increasing applied load, as shown in Fig. 9 and previously noted in Refs. [6, 7, 8, 17, 21, 35]. On the other hand, the increasing distance increased COF by $1 \%-30 \%$ owing to the deterioration of sample surfaces [7]. The average $\mathrm{COF}$ values of $\mathrm{Cu}$ and $\mathrm{Cu}$ composites decreased after sintering and HPT processing. The magnitude of the decrease in COF after HPT was greater than that of sintered samples. The COF decreased by $20 \%-40 \%$ and $50 \%$ after sintering of cold-compacted $\mathrm{Cu}$ and composite samples, respectively. On the other
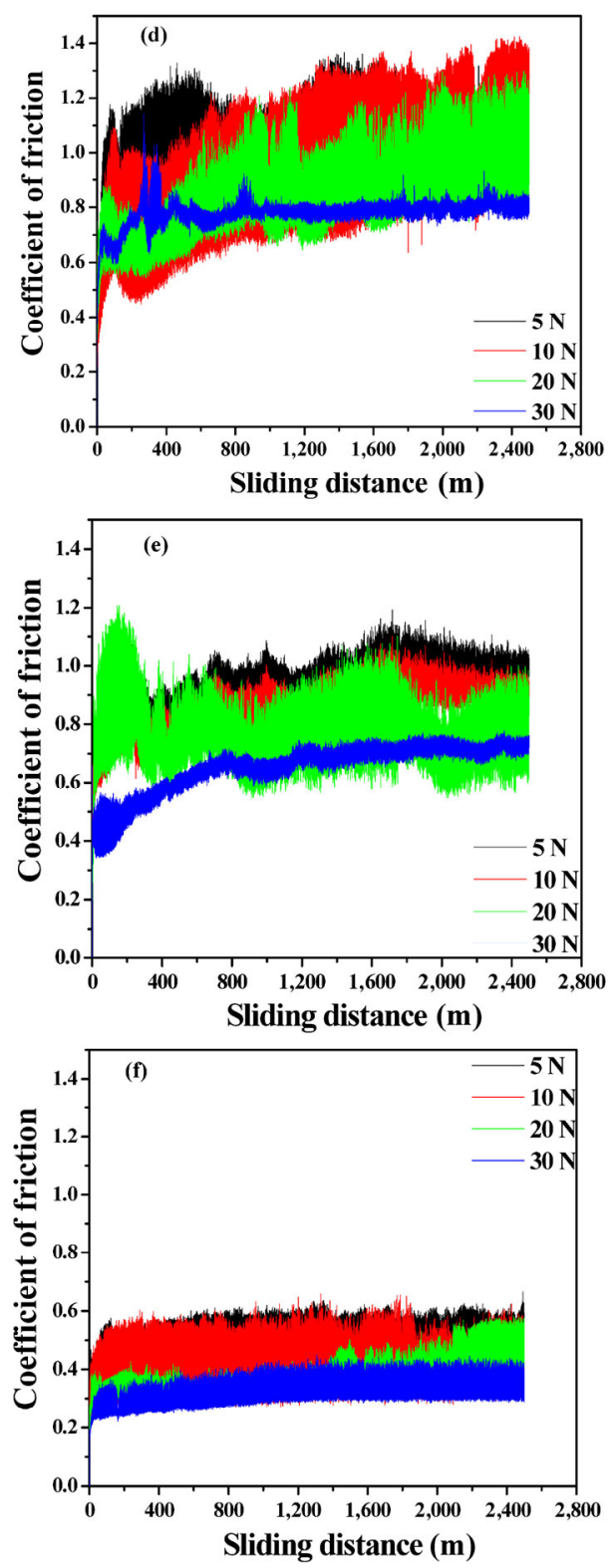

Fig. 8 Variation of COF under different applied loads and sliding distances of $500 \mathrm{~m} \mathrm{(a-c)} \mathrm{and} \mathrm{2,500} \mathrm{m}$ (d-f) of (a and d) cold compacted, (b and e) sintered, and (c and f) HPTed $\mathrm{Cu}-20 \% \mathrm{SiC}$ samples. 

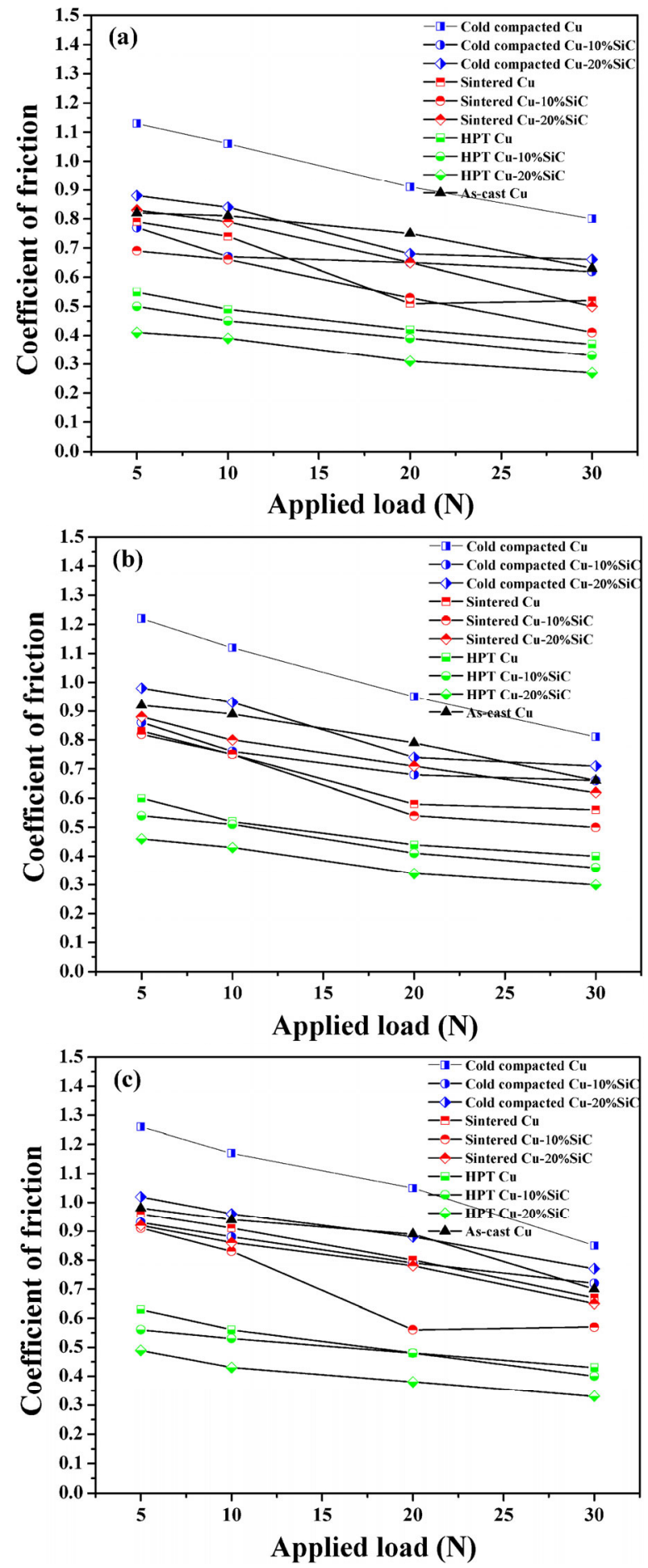

Fig. 9 The effect of the applied load on the average value of the $\mathrm{COF}$ of the as-cast $\mathrm{Cu}$, cold compacted, sintered, and HPTed $\mathrm{Cu}$ and $\mathrm{Cu}-\mathrm{SiC}$ samples under different sliding distances of (a) 500 , (b) 1,500 , and (c) $2,500 \mathrm{~m}$.

hand, the COF of HPTed samples were $50 \%-60 \%$ lower than those of sintered samples. The COF decrease after sintering and HPT processing is attributed to the increase in hardness. However, the COF of HPTed samples was the lowest owing to its high efficiency in grain size decrease, which increased hardness more obviously compared with other methods, as previously noted in SPD of different alloys [17, 18, 20]. Moreover, the samples that contained a mixture of different grain sizes retained a good level of ductility to decrease the degree of damage, and hence the COF.

\subsubsection{Worn surface morphology of copper, copper composites samples, and WC ball}

It can be noted that delamination and adhesion were the dominant wear mechanisms of cold-compacted $\mathrm{Cu}$ samples, with delamination wear increasing with distance, as shown in Fig. 10. The delamination of the surface layer of the sample can be explained as follows. During the sliding of the WC ball due to $\mathrm{Cu}$ softening, $\mathrm{Cu}$ particles were detached from the sample surface and adhered to the ball surface. Then, as the ball continuous to slide, the $\mathrm{Cu}$ particles were returned/re-transferred to the sample surface, forming the delaminated layer (SEM observation of the WC of the ball surface confirmed the results shown in Fig. 10(g)). Furthermore, the worn surface of coldcompacted MMC samples is also characterized by grooves (due to take off the $\mathrm{SiC}$ shown by yellow arrows) and cracks (indicated by red arrows), as shown in Fig. 10. The take off of $\mathrm{SiC}$ particles can be explained by low bonding between the matrix and $\mathrm{SiC}$ particles, which contributes to the presence of the three-body wear mechanism between the sample surface, WC ball, and $\mathrm{SiC}$ particles. This type of the mechanism increases the wear mass loss of cold-compacted composites compared with other materials, as shown in Figs. 2 and 3. The degree of adhesive and delamination wear increased with load, as shown in Fig. 10 and noted previously in Refs. [4, 6, 7, 9]. Oxygen was clearly detected in different cold-compacted samples, as shown in Figs. 11(a) and 11(d), which means that oxidation should be considered as a possible wear mechanism of cold-compacted samples, as previously noted in Ref. [6].

The surface of the wear test ball was not affected by the wear test with cold-compacted $\mathrm{Cu}$ MMC sample. Small localized areas with adhesion and detachment of $\mathrm{Cu}$ on the ball surface were observed, as shown in Fig. $10(\mathrm{~g})$. The transfer and adhesion of $\mathrm{Cu}$ onto the 

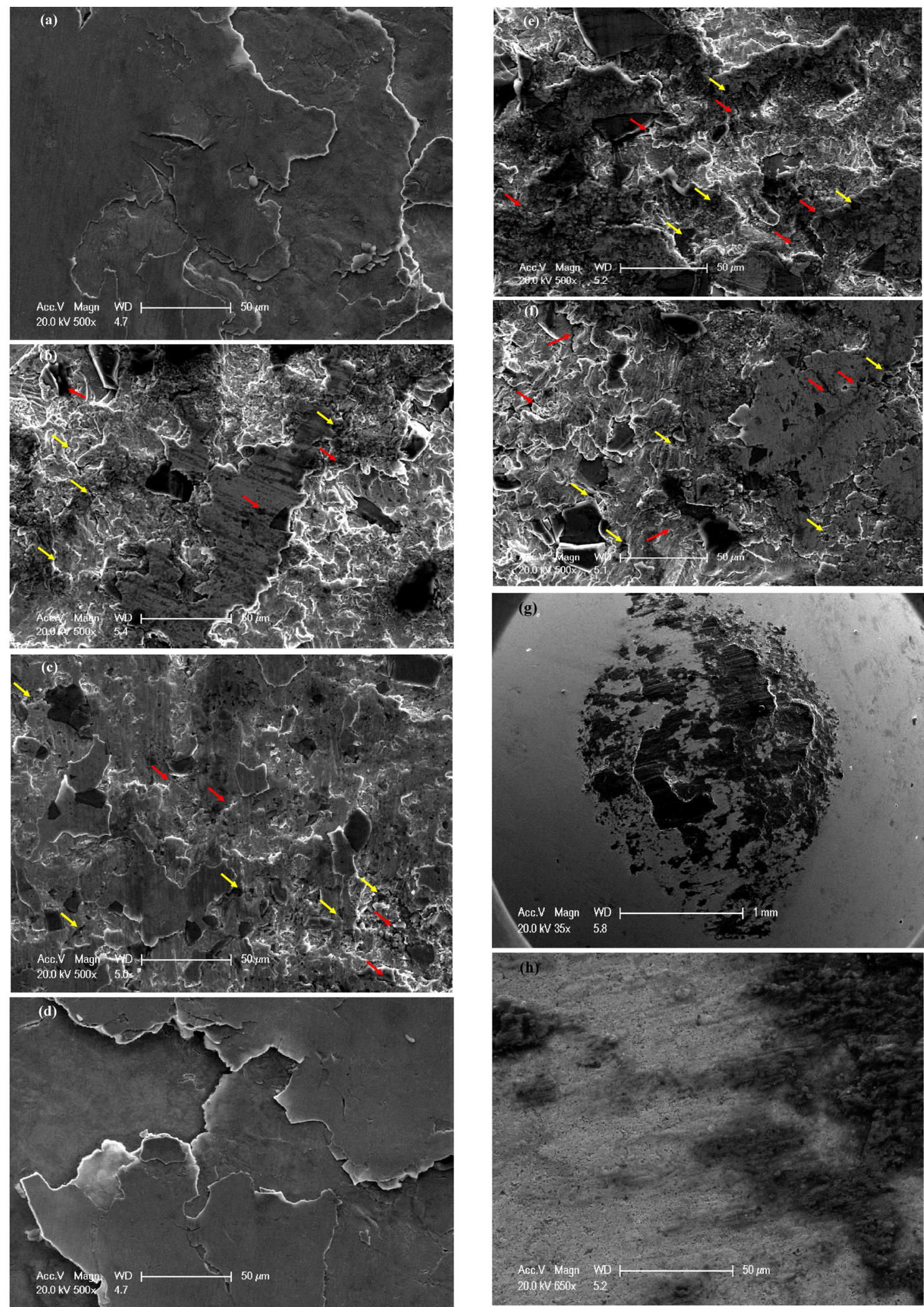

Fig. 10 SEM photograph of the worn surface morphology of $\mathrm{Cu}$ (a and d), $\mathrm{Cu}-10$ (b and e), and $20 \% \mathrm{SiC}$ ( $\mathrm{c}$ and $\mathrm{f}$ ) cold compacted samples corresponding to a sliding distance of 2,500 $\mathrm{m}$ and applied loads of $5 \mathrm{~N}(\mathrm{a}-\mathrm{c})$ and $30 \mathrm{~N}(\mathrm{~d}-\mathrm{f})$, and $(\mathrm{g}-\mathrm{h})$ the corresponding WC wear surface morphology after the sliding against $\mathrm{Cu}-20 \% \mathrm{SiC}$ cold compacted sample under sliding distance of $2,500 \mathrm{~m}$ and an applied load of $30 \mathrm{~N}$ under different magnifications. 

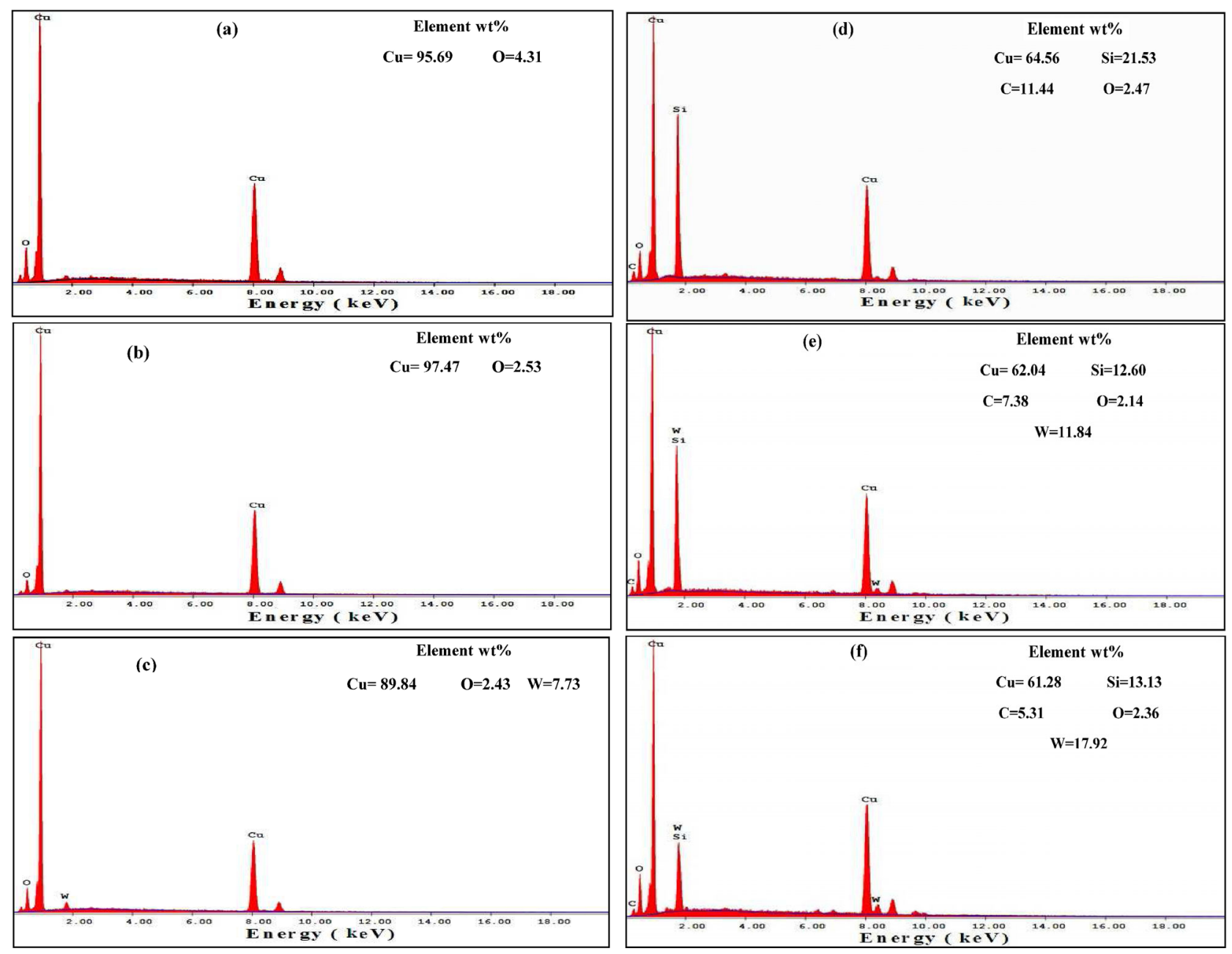

Fig. 11 EDS analysis of worn surface of $(a-c) \mathrm{Cu}$ and $(\mathrm{d}-\mathrm{f}) \mathrm{Cu}-20 \% \mathrm{SiC}$ cold compacted (a and $d)$, sintered $(\mathrm{b}$ and e), and HPTed samples ( $\mathrm{c}$ and $\mathrm{f}$ ) corresponding to a sliding distance of 2,500 $\mathrm{m}$ and an applied load of $30 \mathrm{~N}$

WC ball surface hindered the ball from sliding against the cold-compacted samples, which confirms the high COF of cold-compacted samples as shown in Figs. 7-9. High magnification of the WC ball surface revealed a polished surface with adhesion of $\mathrm{Cu}$ in a dark color, as shown in Fig. 10(h). The ball surface was also free of plastic deformation bands or scratches.

The wear mechanism of the sintered $\mathrm{Cu}$ sample is a combination of adhesive, abrasive, and low degree of delamination with increasing adhesive wear, applied load, and sliding distance, as shown in Fig. 12. The worn surface of the sintered $\mathrm{Cu}$ composite sample was free of grooves and cracks observed in cold-compacted samples. These observations confirm the capability of the sintering process in improving wear resistance. Oxygen was found in the analysis of worn sintered samples, as shown in Fig. 11, which makes oxidation the wear mechanism of sintered samples. Moreover, tungsten (W) with percentage of $11.84 \%$ was found in the analysis of the surface of worn sintered $\mathrm{Cu}$ MMC samples. This observation is attributed to the increase inbonding; thus, the hardness of the $\mathrm{Cu}-\mathrm{SiC}$ after the sintering process makes it capable of removing a significant amount from the WC ball. After the sintering process, the wear of the WC ball becomes clear with an area of $1.23 \mathrm{~mm}^{2}$, as indicated in Figs. 12(g)-12(h). The ball used in testing the sintered $\mathrm{Cu}$ MMCs has a rough surface with the presence of voids, as shown in Fig. 12(h), and confirmed by $W$ transfer to the wear sample by EDS of sintered Cu MMCs.

Figure 13 shows the worn surface morphology of the HPTed samples under applied loads of 5 and $30 \mathrm{~N}$ 

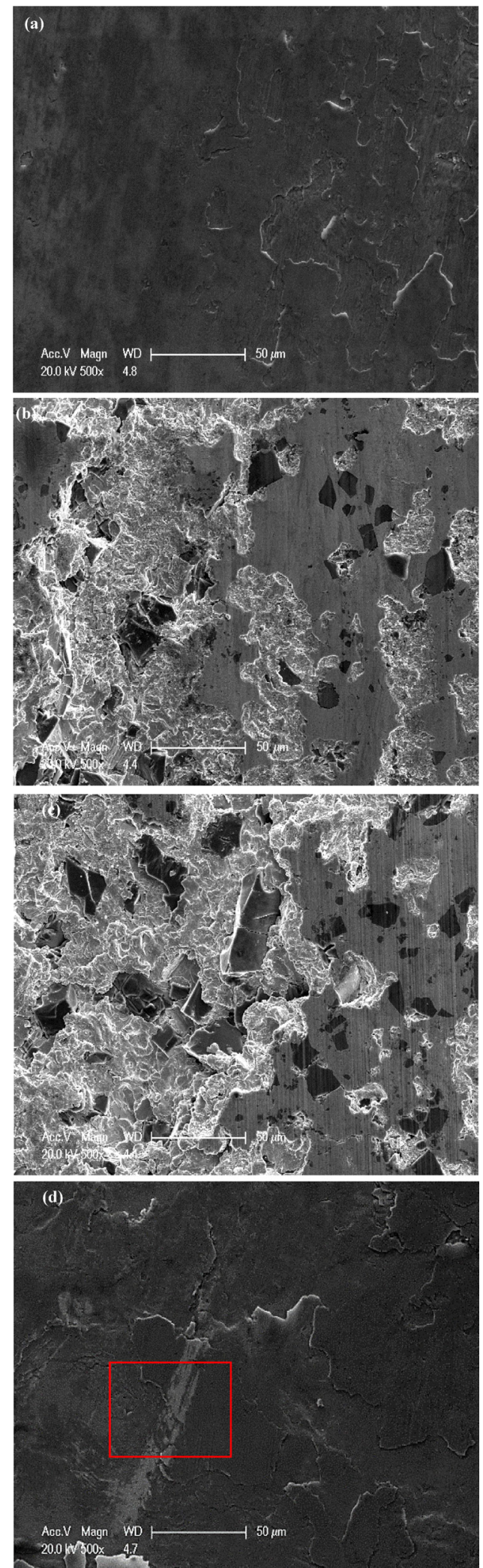
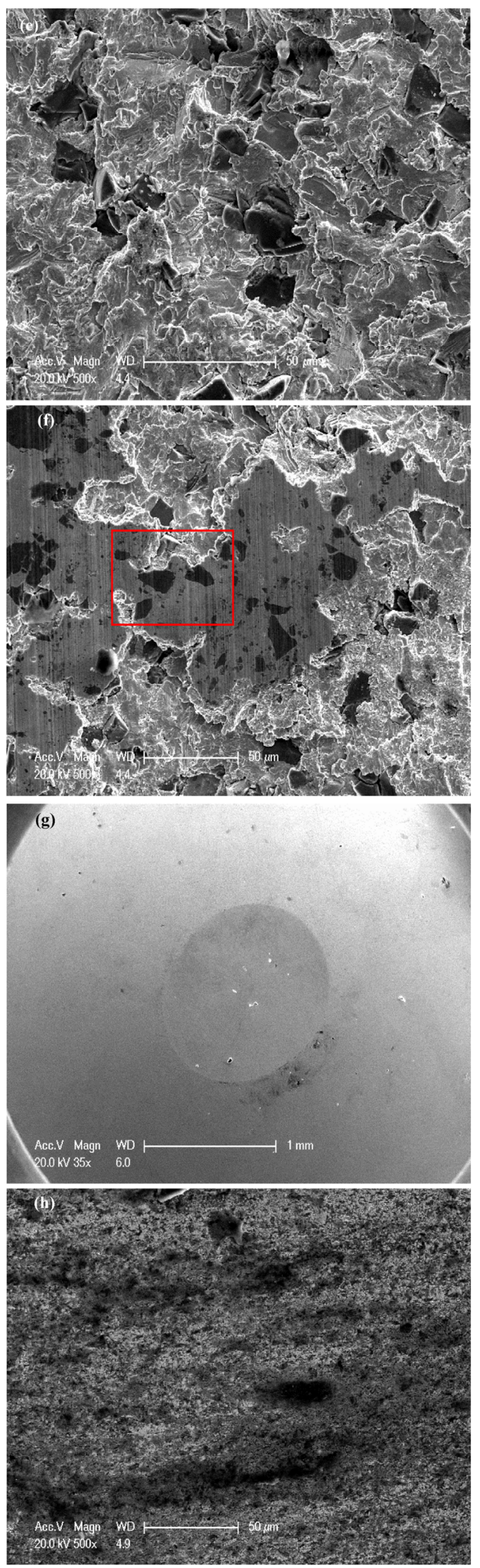

Fig. 12 SEM photograph of the worn surface morphology of $\mathrm{Cu}$ (a and d), Cu-10 (b and e) and 20\%SiC (c and f) sintered samples corresponding to a sliding distance of 2,500 $\mathrm{m}$ and applied loads of $5 \mathrm{~N}(\mathrm{a}-\mathrm{c})$ and $30 \mathrm{~N}(\mathrm{~d}-\mathrm{f})$, and $(\mathrm{g}-\mathrm{h})$ the corresponding WC wear surface morphology after the sliding against $\mathrm{Cu}-20 \% \mathrm{SiC}$ sintered sample under sliding distance of $2,500 \mathrm{~m}$ and an applied load of $30 \mathrm{~N}$ under different magnifications. 

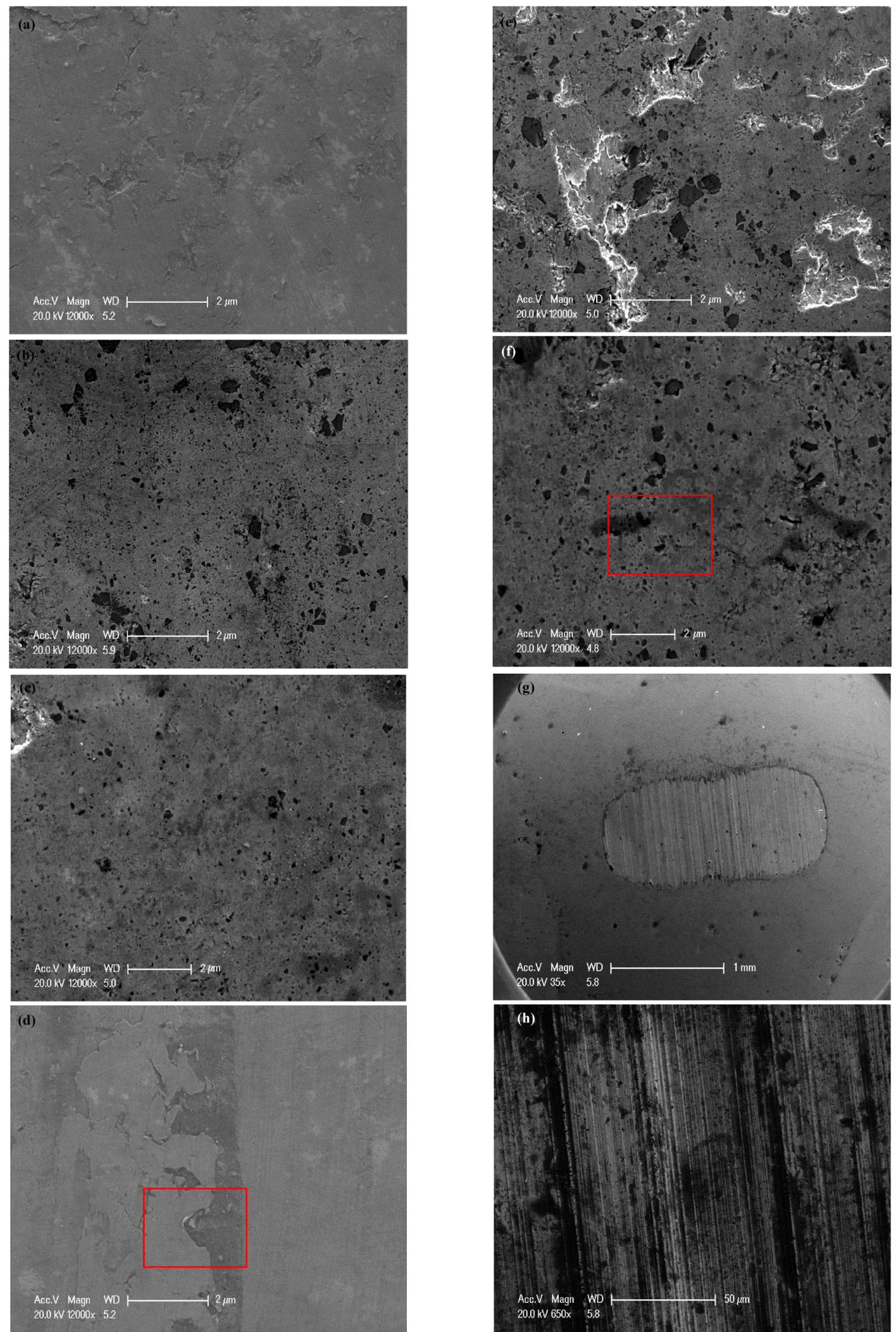

Fig. 13 SEM photograph of the worn surface morphology of $\mathrm{Cu}$ (a and d), Cu-10 (b and e), and 20\%SiC (c and f) HPTed samples corresponding to a sliding distance of 2,500 $\mathrm{m}$ and applied loads of $5 \mathrm{~N}(\mathrm{a}-\mathrm{c})$ and $30 \mathrm{~N}(\mathrm{~d}-\mathrm{f})$, and $(\mathrm{g}-\mathrm{h})$ the corresponding WC wear surface morphology after the sliding against $\mathrm{Cu}-20 \% \mathrm{SiC}$ HPTed sample under sliding distance of 2,500 m and an applied load of $30 \mathrm{~N}$ under different magnifications. 
and 2,500 $\mathrm{m}$. The worn surface morphology of the HPTed samples can characterized by abrasive wear, which is considered the main wear mechanism of HPTed samples. It is also noted that the worn surface of HPTed samples has a more homogenized distribution of $\mathrm{SiC}$ particles than in other cases, which contributes to the increase in wear resistance. Interestingly, no grooves and cracks were found in the HPTed $\mathrm{Cu}-\mathrm{SiC}$ case owing to its strong bonding, as shown in Fig. 13. The formation of microstructures with multiple grain and particle sizes is the main reason for the change of the wear mechanism to abrasive wear after HPT. The refinement of $\mathrm{Cu}$ grain size with the fragmentation of $\mathrm{SiC}$ particles increased the hardness, and thus transformed the wear mechanism into abrasive wear [4, 9, 17-20, 25-27, 29]. Furthermore, the microstructure with multiple grain and particle sizes [34] decreased the degree of wear compared with that in the nanocomposites [9, 11, 27, 28, 35].
The analysis of HPTed $\mathrm{Cu}$ and $\mathrm{Cu}$ MMC samples indicate the presence of $\mathrm{W}$, as noted in Fig. 11. Moreover, the amount of W in HPTed Cu MMC sample surface was two times that in the sintered sample shown in Fig. 11(e). The high W content on the surface of HPTed samples is due to their higher hardness. Furthermore, oxygen was found, as shown in Figs. 11(c) and 11(f), which makes oxidation a wear mechanism in all samples in the present work. Severe wear with a large area of $2 \mathrm{~mm}^{2}$ was noted in the case of the WC ball after wear test of HPTed MMCs, as shown in Figs. 13(g) and 13(h). Therefore, HPTed samples have a higher effect on increasing the wear of the WC ball owing to its high hardness, which transfers a large amount of $\mathrm{W}$ onto the sample surface, as shown in Fig. 11(f).

Figure 14 shows SEM photo micrographs and EDS of the as-cast $\mathrm{Cu}$ sample after wear test under applied loads of $5 \mathrm{~N}$ and $30 \mathrm{~N}$ and sliding distance of 2,500 m.

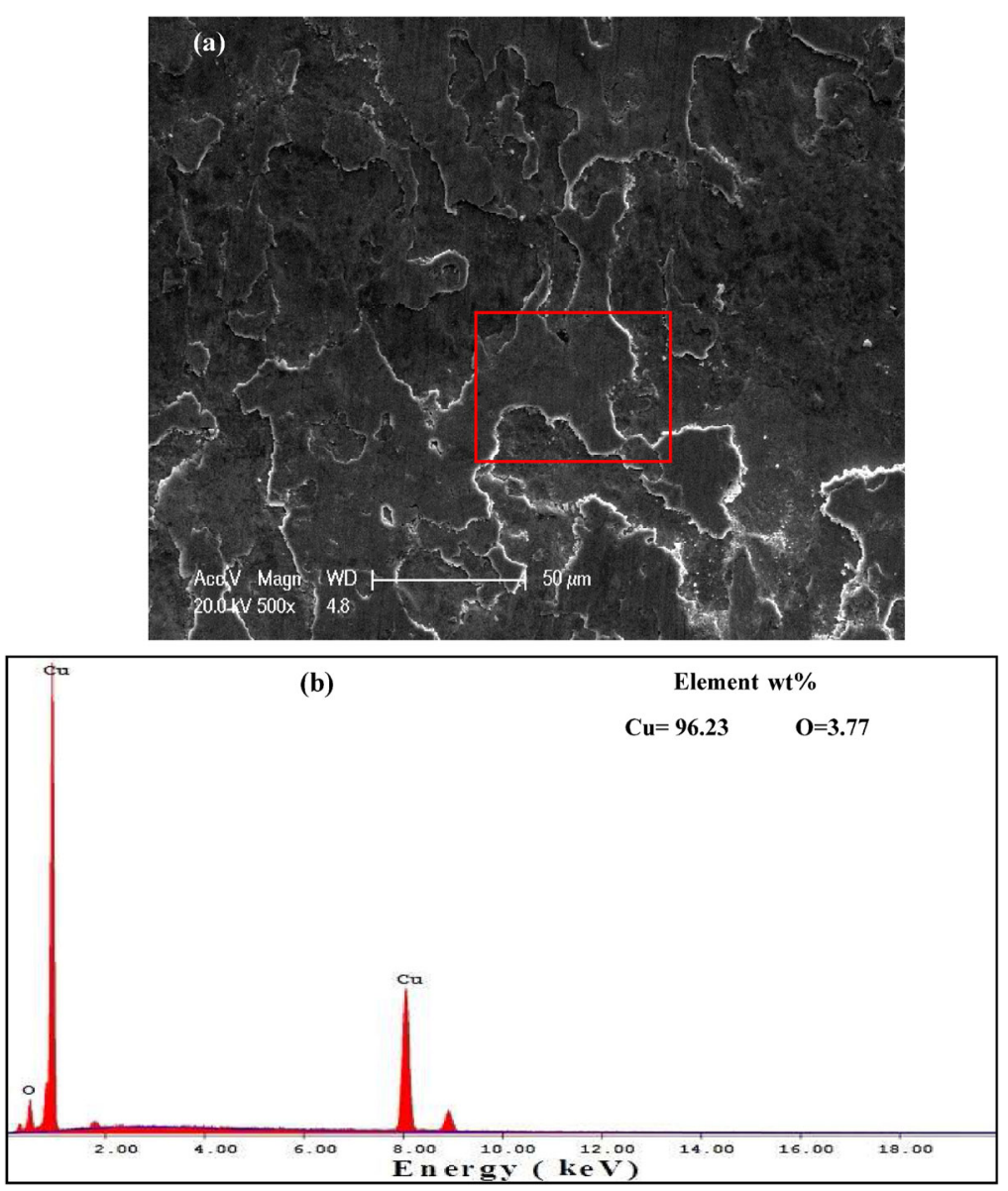

Fig. 14 SEM photograph and EDS analysis of worn surface of the as-cast $\mathrm{Cu}$ corresponding to sliding distance of 2,500 $\mathrm{m}$ and applied loads of $(\mathrm{a}-\mathrm{b}) 5 \mathrm{~N}$ and $(\mathrm{c}-\mathrm{d}) 30 \mathrm{~N}$. 

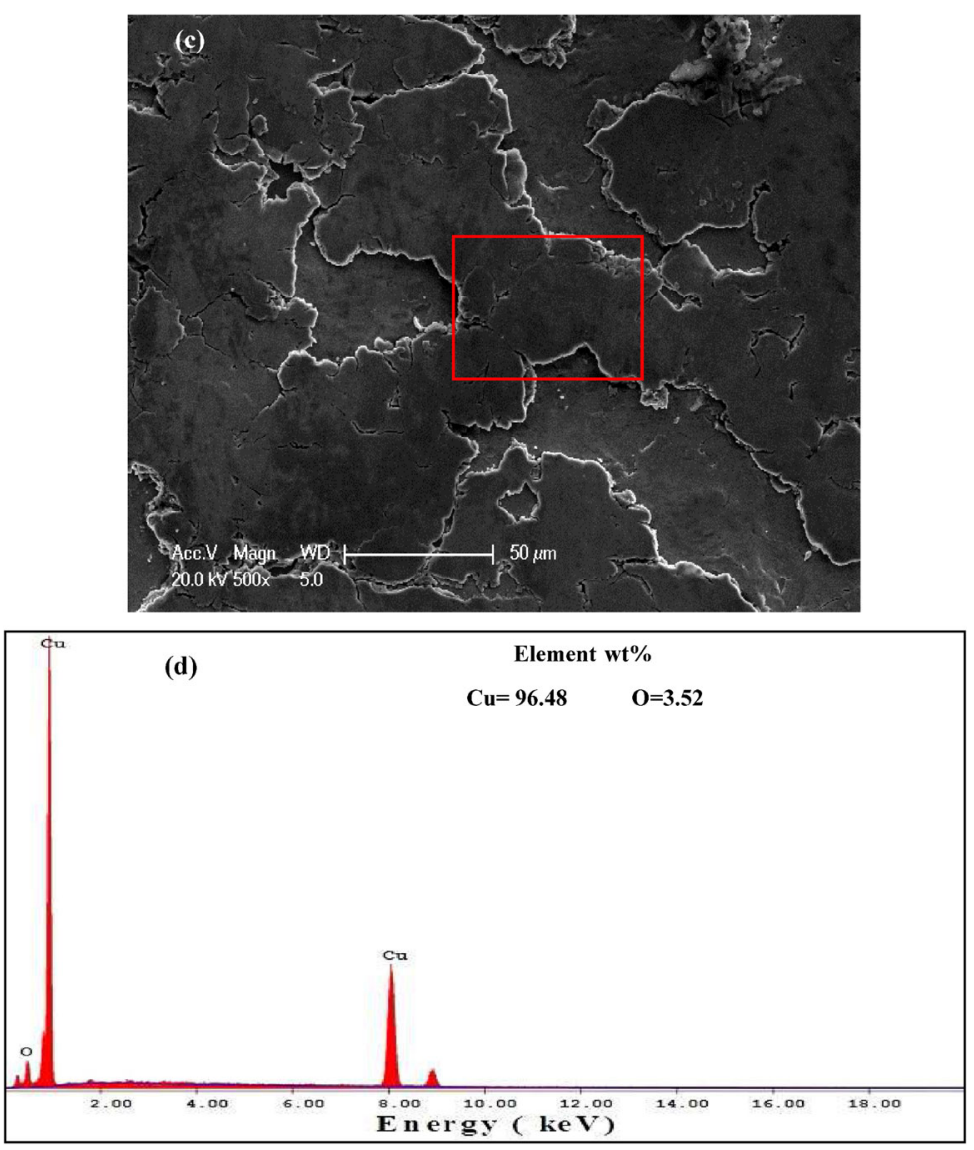

Fig. 14 (Continued)

The dominant wear mechanisms in as-cast $\mathrm{Cu}$ samples under different conditions were delamination and adhesive wear. It was also observed that the wear in worn cold-compacted $\mathrm{Cu}$ was more severe than that of as-cast $\mathrm{Cu}$ sample, as shown in Figs. 10(a) and 10(d), and Figs. 14(a) and 14(c), respectively. The high wear resistance of as-cast $\mathrm{Cu}$ sample relative to cold-compacted $\mathrm{Cu}$ is due to its higher hardness. On the other hand, the wear of as-cast $\mathrm{Cu}$ samples under applied loads of $5 \mathrm{~N}$ and $30 \mathrm{~N}$ and sliding distances of 2,500 $\mathrm{m}$ was greater than that of $\mathrm{Cu}$ HPTed samples under same conditions, as shown in Figs. 14(a) and 14(b). Therefore, the HPTed $\mathrm{Cu}$ samples have higher wear resistance compared with as-cast, cold-compacted, and sintered samples. The EDS analysis confirmed oxidation as the wear mechanism of as-cast sample. There was no evidence of the presence of $\mathrm{W}$ on the as-cast $\mathrm{Cu}$ sample surface.

Therefore, the wear mechanisms can be summarized as grooves (due to the $\mathrm{SiC}$ particle take off) that lead to three-body wear mechanism, delamination, and cracks in the cold-compacted samples. With the increase of bonding and thus hardness after the sintering process, the wear mechanism changed to a lower degree of delamination, with the presence of adhesive and abrasive wear mechanisms. Finally, after HPT processing, the wear mechanism was abrasive wear owing to the superior hardness of HPTed samples. Interestingly, for all cases, oxidation was main wear mechanism as indicated by EDS under all wear conditions.

\section{Conclusions}

In the current research, it can conclude that:

(1) HPT of $\mathrm{Cu}$ and $\mathrm{Cu}$ MMCs with microsize powders improves their wear resistance. The formation of a microstructure with different grain and particle sizes decreases the wear mass loss after HPT by $70 \%-97 \%$ compared with samples fabricated by other methods.

(2) HPTed samples have higher wear resistance (by 
25\%-100\%) than $\mathrm{Cu}$ and $\mathrm{Cu}$ MMCs consisting of large and fine matrix grains and reinforcement particles in the present and previous works.

(3) The COF of the cold-compacted $\mathrm{Cu}$ and $\mathrm{Cu}$ composites decreased by $2 \%-40 \%$ and $32 \%-60 \%$ after sintering and HPT, respectively, because of the change inmaterial processing method, and thus the hardness increased.

(4) The sample fabrication method has an obvious influence on the wear mechanism.

(5) The SEM photo micrographs and EDS patterns of the wear samples and WC ball confirm the wear mass loss, friction, and wear mechanism results.

Open Access This article is licensed under a Creative Commons Attribution 4.0 International License, which permits use, sharing, adaptation, distribution and reproduction in any medium or format, as long as you give appropriate credit to the original author(s) and the source, provide a link to the Creative Commons licence, and indicate if changes were made.

The images or other third party material in this article are included in the article's Creative Commons licence, unless indicated otherwise in a credit line to the material. If material is not included in the article's Creative Commons licence and your intended use is not permitted by statutory regulation or exceeds the permitted use, you will need to obtain permission directly from the copyright holder.

To view a copy of this licence, visit http://creativecommons.org/licenses/by/4.0/.

\section{References}

[1] Pascoe K J. An Introduction to the Properties of Engineering Materials. UK: Van Nostrand Reinhold (UK) Co. Ltd, 1982.

[2] Mallick P K. Composites Engineering Handbook. Marcel Dekker Inc, 1997.

[3] Ralph B, Yuen H C, Lee W B. The processing of metal matrix composites-An overview. J Mater Process Technol 63: 339-353 (1997)

[4] Tjong S C, Lau K C. Tribological behaviour of SiC particlereinforced copper matrix composites. Mater Lett 43: 274-280 (2000)

[5] Moustafa S F, Abdel-Hamid Z, Abd-Elhay A M. Copper matrix $\mathrm{SiC}$ and $\mathrm{Al}_{2} \mathrm{O}_{3}$ particulate composites by powder metallurgy technique. Mater Lett 53: 244-249 (2002)
[6] Dhokey N B, Paretkar R K. Study of wear mechanisms in copper-based $\mathrm{SiCp}$ (20\% by volume) reinforced composite. Wear 265: 117-133 (2008)

[7] Ramesh C S, Ahmed R N, Mujeebu M A, Abdullah M Z. Development and performance analysis of novel cast copperSiC-Gr hybrid composites. Mater Des 30: 1957-1965 (2009)

[8] Vettivel S C, Selvakumar N, Leema N, Lenin A H. Electrical resistivity, wear map and modeling of extruded tungsten reinforced copper composite. Mater Des 56: 791-806 (2016)

[9] Shabani M, Paydar M H, Zamiri R, Goodarzi M, Moshksar M M. Microstructural and sliding wear behavior of SiCparticle reinforced copper matrix composites fabricated by sintering and sinter-forging processes. J Mater Res Tecnol 5(1): 5-12 (2016)

[10] Hausner H H. Modern Developments in Powder Metallurgy. New York: Plenum Press, 1966.

[11] Zhu J, Liu L, Zhao H, Shen B, Hu W. Microstructure and performance of electroformed $\mathrm{Cu} /$ nano-SiC composite. Mater Des 28: 1958-1962 (2007)

[12] Fathy A, Shehata F, Abdelhameed M, Elmahdy M. Compressive and wear resistance of nanometric alumina reinforced copper matrix composites. Mater Des 36: 100-107 (2012)

[13] Akramifard H R, Shamanian M, Sabbaghian M, Esmailzadeh $\mathrm{M}$. Microstructure and mechanical properties of $\mathrm{Cu} / \mathrm{SiC}$ metal matrix composite fabricated via friction stir processing. Mater Des 54: 838-844 (2014)

[14] Barmouz M, Asadi P, Givi M K B, Taherishargh M. Investigation of mechanical properties of $\mathrm{Cu} / \mathrm{SiC}$ composite fabricated by FSP: Effect of SiC particles' size and volume fraction. Mater Sci Eng A 528: 1740-1749 (2011)

[15] Abd El Aal M I, El Mahallawy N, Shehata F A, Abd El Hameed M, Yoon E Y, Kim H S. Wear properties of ECAP-processed ultrafine grained Al-Cu alloys. Mater Sci Eng A 527: 3726-3732 (2010)

[16] Abd El Aal M I. The effect of the pre-homogenization treatment on the fracture characteristics and wear properties of ECAPed Al-Cu alloys. Mater Sci Eng A 539: 308-323 (2012)

[17] Li J, Wongsa-Ngam J, Xu J, Shan D, Guo B, Langdon T G. Wear resistance of an ultrafine-grained $\mathrm{Cu}-\mathrm{Zr}$ alloy processed by equal-channel angular pressing. Wear 326-327: 10-19 (2015)

[18] Huang S J, Semenov V I, Shuster L S, Lin P C. Tribological properties of the low-carbon steels with different microstructure processed by heat treatment and severe plastic deformation. Wear 271: 705-711(2011)

[19] Ebrahimi M, Attarilar S, Djavanroodi F, Gode C, Kim H S. Wear properties of brass samples subjected to constrained groove pressing process. Mater Des 63: 531-537(2014) 
[20] Abd El Aal M I, Kim H S. Wear properties of high pressure torsion processed ultrafine grained $\mathrm{Al}-7 \% \mathrm{Si}$ alloy. Mater Des 53: 373-382 (2014)

[21] Edalati K, Ashida M, Horita Z, Matsui T , Kato H. Wear resistance and tribological features of pure aluminum and $\mathrm{Al}-\mathrm{Al}_{2} \mathrm{O}_{3}$ composites consolidated by high-pressure torsion. Wear 310(1-2): 83-89 (2014)

[22] Gode C, Yilmazer H, Ozdemir I, Todaka Y. Microstructural refinement and wear property of $\mathrm{Al}-\mathrm{Si}-\mathrm{Cu}$ composite subjected to extrusion and high-pressure torsion. Mater Sci Eng A 618: 377-384 (2014)

[23] Abd El Aal M I. Effect of high-pressure torsion processing on the microstructure evolution and mechanical properties of consolidated micro size $\mathrm{Cu}$ and $\mathrm{Cu}-\mathrm{SiC}$ powders. Adv Pow Technol 28(9): 2135-2150 (2017)

[24] Archard J F. Contact and rubbing of flat surfaces. J Appl Phys 24: 981-988 (1953)

[25] Ming H, Yunlong Z, Lili T, Lin S, Jing G, Peiling D. Surface modifying of $\mathrm{SiC}$ particles and performance analysis of SiCp/Cu composites. Appl Sur Sci 332: 720-725 (2015)

[26] Hashemi M, MirdamadiSh, RezaieH R. Effect of SiC nanoparticles on microstructure and wear behavior of $\mathrm{Cu}-\mathrm{Ni}-\mathrm{W}$ nanocrystalline coating. Elect Acta 138: 224-231(2014)

[27] Safari F, Khosroshah R A, Zolriasatein A. Wear behavior of copper matrix composites reinforced by $\gamma-\mathrm{Cu}_{5} \mathrm{Zn}_{8}$

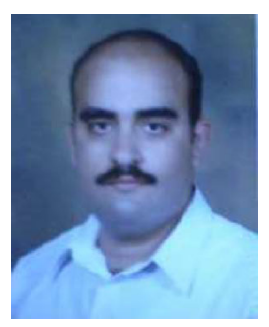

Mohamed Ibrahim Abd El AAL. He received his M.S. and Ph.D. degrees in mechanical engineering (mechanical design and production engineering) from Zagazig University, Egypt, in 2005 and 2010, respectively. He joined the Mechanical Design nanoparticles. Pow Technol 318: 549-557(2017)

[28] Tu J P, Yang Y Z, Wang L Y, Ma X C, Zhang X B. Tribological properties of carbon-nanotube-reinforced copper composites. Tribol Lett 10(4): 225-228 (2001)

[29] Hornbogen E. The role of fracture toughness in the wear of metals. Wear 33: 251-259 (1975)

[30] Koch C C. Optimization of strength and ductility in nanocrystalline and ultrafine grained metals. Scripta Materialia 49: 657-66 2 (2003)

[31] Zhang P, An X H, Zhang Z J, Wu S D, Li S X, Zhang Z F, Figueiredo R B, Gao N, Langdon T G. Optimizing strength and ductility of $\mathrm{Cu}-\mathrm{Zn}$ alloys through severe plastic deformation. Scripta Materialia 67: 871-874 (2012)

[32] Sevim I, Eryurek I B. Effect of fracture toughness on abrasive wear resistance of steels. Mater Des 27: 911-919 (2006)

[33] Zhou L, Liu G, Han Z, Lu K. Grain size effect on wear resistance of a nanostructured AISI52100 steel. Scripta Materialia 58(6): 445-448 (2008)

[34] Wang H, Yang T, Song X, Liu X, Wang X, Wu X. Wear resistance enhancement of bimodal-grained cemented carbide coating. Surf Coat Technol 309: 759-766 (2017)

[35] Akbarpour M R, Alipour S. Wear and friction properties of spark plasma sintered $\mathrm{SiC} / \mathrm{Cu}$ nanocomposites. Ceram Int 43(16): 13364-13370 (2017)

and Production Engineering Department at Faculty of Engineering at Zagazig University from 2000. His current position is associate professor. His research areas cover the manufacturing, characteristics and tribologyof SPD processed material, nano metal matrix composites, recycling of metals chips, and traditional and nontraditional machining of materials. 